\title{
Pelaksanaan Tugas Kecamatan Guna Memberdayakan Pemerintah sebagai Pusat Pelayanan Masyarakat
}

\author{
MASANA SEMBIRING \\ IPDN, Jatinangor, Jl. Raya Bandung-Sumedang KM 20, Kode Pos 45363 \\ email: masanasembiring@ymail.com
}

\begin{abstract}
The decrease of public services is expected due to the lack of empowerment of Government of Jatinangor District as one of the regional leading the field of performing general government in coordinating, training and field of services to the community. The study is a descriptive research design with qualitative approach. The purpose of this study is to describe the implementation of common tasks of Government Jatinangor District in the field of coordination, training and field of services to the community and describe how the Government Jatinangor District to be a central of public empowering. The results showed that the implementation of the general governance of Government Jatinangor District in the field of coordination, training and field of services to the community is not optimal as expected, due to less optimal implementation of the district authority and the lack of available elements of Personnel, Finance and Infrastructure and Facilities.
\end{abstract}

Keywords: coordinating, training and field of services to the community

\begin{abstract}
Abstrak. Kurangnya pelayanan kepada masyarakat diperkirakan karena kurangnya pemberdayaan pemerintah Kecamatan Jatinangor sebagai salah satu Organisasi Perangkat Daerah terdepan yang melaksanakan tugas umum pemerintahan bidang koordinasi, pembinaan dan bidang pelayanan kepada masyarakat. Desain penelitian yang digunakan adalah desain penelitian deskriptif pendekatan kualitatif. Tujuan penelitian ini untuk menggambarkan pelaksanaan tugas umum Pemerintah Kecamatan Jatinangor bidang koordinasi, pembinaan dan bidang pelayanan kepada masyarakat dan menggambarkan cara memberdayakan Pemerintah Kecamatan Jatinangor sebagai pusat pelayanan masyarakat. Hasil penelitian menunjukkan bahwa pelaksanaan tugas umum pemerintahan Pemerintah Kecamatan Jatinangor bidang koordinasi, pembinaan dan bidang pelayanan kepada masyarakat belum optimal sesuai harapan, karena kurang optimalnya implementasi kewenangan kecamatan dan kurang tersedianya unsur 3P (Personalia, Pembiayaan dan Prasarana dan Sarana).
\end{abstract}

Kata Kunci: koordinasi, pembinaan, pelayanan, pemberdayaan masyarakat

\section{Pendahuluan}

Pemberdayaan pemerintah kecamatan sebagai pusat pelayanan masyarakat terkait dengan artikel Zamzami dalam Jurnal Sosial dan Pembangunan MIMBAR (2011: 123) yang berpendapat bahwa pelaksanaan program Pemberdayaan Ekonomi Masyarakat Pesisir (PEMP) belum optimal, sehingga perlu ditingkatkan baik oleh pemerintah maupun oleh masyarakat peserta program. Pemerintah kecamatan merupakan bagian yang tak terpisahkan dari sistem pemerintahan Indonesia yang menjalankan tata kelola kepemerintahan yang baik. Tata kelola kepemerintahan yang baik (Good Governance) menjalankan fungsi pengaturan, pelayanan dan pemberdayaan masyarakat (LAN RI, 2004). Bupati selaku kepala daerah berperan menjalankan fungsi pemerintahan. Hal tersebut sesuai dengan apa yang dikemukakan oleh Smith (2007: 4) bahwa:

governance have the role to play in the formulation and implementasion of public policy and the delivery of public services.

Untuk menyelenggarakan fungsi tersebut sehari-hari, maka kepala daerah dibantu oleh birokrasi pemerintahan daerah selaku pejabat karier yang biasa disebut Organisasi Perangkat Daerah (OPD) berdasarkan Peraturan Pemerintah Nomor 41 Tahun 2007, tentang Organisasi Perangkat Daerah pada pasal 1 butir 8, di mana kecamatan sebagai salah satu perangkat daerah.

Kebijakan otonomi daerah berdasarkan Undang-Undang No. 32 Tahun 2004, tentang 
Pemerintahan Daerah bahwa kecamatan berubah statusnya dari perangkat wilayah menjadi perangkat daerah. Kecamatan disamakan kedudukannya dengan OPD lainnya seperti dinas daerah dan LTD. Dengan demikian sebagai perangkat daerah semestinya kecamatan diperlakukan sama dengan dinas daerah dan lembaga teknis daerah lainnya dalam memeroleh hak dan dalam melaksanakan kewajibannya masing-masing.

Masalah penelitian menurut pengamatan peneliti adalah kurang optimalnya pelaksanaan tugas umum pemerintahan Kecamatan Jatinangor terutama bidang koordinasi, pembinaan, dan bidang pelayanan masyarakat, karena kurangnya kewenangan yang jelas serta kurangnya unsur $3 P$ (Personel, Pembiayaan dan Prasarana dan Sarana).

Sehubungan masalah tersebut, mendorong penulis untuk mengetahui pelaksanaan tugas umum pemerintahan Kecamatan Jatinangor melalui penelitian. Rumusan masalah penelitian ini adalah, "Bagaimana gambaran pelaksanaan tugas umum Pemerintahan Camat Kecamatan Jatinangor Kabupaten Sumedang, dari aspek koordinasi, pembinaan dan pelayanan masyarakat dan bagaimana memberdayakan Pemerintah Kecamatan Jatinangor sebagai pusat pelayanan masyarakat di Kecamatan Jatinangor Kabupaten Sumedang." Desain penelitian yang digunakan adalah desain penelitian tipe deskriptif pendekatan kualitatif (Arikunto, 2002). Sumber data dan informasi ditentukan sendiri sesuai kompetensinya sebanyak 8 responden. Langkah-langkah dalam analisis data yaitu editing, klasifikasi data, tabulasi dan interpretasi (Nazir, 2005).

\section{Fungsi Pemerintah Kecamatan, Kordinasi dan Pembinaan}

Untuk mewujudkan kehidupan masyarakat yang sejahtera, adil dan makmur diperlukan tata kelola kepemerintahan yang baik. LAN dan BPKP (2000) mengemukakan bahwa tata kelola kepemerintahan yang baik adalah proses kerjasama dan sinerji diantara sektor pemerintah (state), sektor swasta (private) dan masyarakat (society) yang mampu melaporkan secara transparan tentang keberhasilan dan kegagalannya kepada masyarakat dalam rangka mencapai tujuan negara. Tata kelola kepemerintahan yang baik harus berdasarkan kebijakan publik yang diaplikasikan oleh pemerintah melalui sistem administrasi dan manajemen (Nugroho D, 2003). Kecamatan sebagai organisasi digerakkan melalui sistem administrasi dan manajemen dalam hal ini pemerintah kecamatan dimana administrasi mengeluarkan kebijakan dan manajemen melaksanakan kebijakan tersebut (Siagian, 2008). Organisasi, administrasi dan manajemen merupakan satu kesatuan yang tak terpisahkan. Organisasi sebagai wadah bersifat statis sedangkan administrasi dan manajemen bersifat dinamis dan administrasi publik merupakan bagian administrasi berupaya melaksanakan kebijakan publik (public policy) untuk kepentingan publik (Thoha, 2008). Hal ini sesuai dengan pendapat Shafritz. at.al (2011:6) bahwa

public administration is what Government does and the management of public affairs or the implementation of public policies.

Sebagai organisasi maka pemerintah Kecamatan Jatinangor menjalankan fungsi perencanaan, pengorganisasian, penggerakan dan fungsi pengawasan berdasarkan tugas pokok dan fungsinya bidang koordinasi, pembinaan dan bidang pelayanan masyarakat.

Organisasi kecamatan sebagai wadah kerjasama, sementara manajemen (para Kepala Seksi) adalah alat administrasi untuk mencapai tujuan yang efektif dan efisien. Administrasi berorientasi pada keteraturan yang efektif dan efisien (Alie, 2004). Oleh karena itu, organisasi kecamatan harus berlandaskan konsep-konsep tersebut dalam melaksanakan tugas pokok dan fungsinya secara teratur, efektif dan efisien.

Berdasarkan pasal 15 Peraturan Pemerintah Nomor 19 Tahun 2008, tugas umum pemerintahan Camat terdiri dari lima tugas koordinasi pemerintahan, satu tugas pembinaan penyelenggaraan pemerintahan desa dan atau/ kelurahan dan satu tugas pelayanan masyarakat. Peraturan Pemerintah Nomor 19 Tahun 2008 tersebut kemudian ditegaskan dalam Peraturan Bupati Nomor 31 Tahun 2009, tentang Uraian Tugas Jabatan Struktural Pada Kecamatan Kabupaten Sumedang. Tugas-tugas delegatif sebanyak 22 bidang kewenangan/urusan yang dilimpahkan oleh Bupati Sumedang kepada Camat Jatinangor berdasarkan Peraturan Bupati Sumedang Nomor 55 Tahun 2009.

Berdasarkan uraian di atas dapat dilihat bahwa tugas dan tanggung jawab Kecamatan Jatinangor sangat berat dan kompleks terkait dengan tugas atributif dan tugas delegatif, namun tugas delegatif (pelimpahan kewenangan) tersebut dinilai belum memenuhi prinsip keadilan, karena di dalam peraturan Bupati tersebut tidak ada pasal yang mengatur pembiayaan pelaksanaan kewenangan tersebut, sehingga pelimpahan kewenangan tersebut tidak efektif dalam pelaksanaannya. Untuk menjalankan tugas dan kewenangan kecamatan dibentuk organisasi kecamatan berdasarkan Perda Kabupaten Sumedang Nomor 8 Tahun 2008. Organisasi Kecamatan Jatinangor terdiri dari jabatan struktural Camat, Sekretariat Kecamatan, Sub Bagian (3) dan Seksi (5) yang uraian jabatannya diatur 
berdasarkan Peraturan Bupati Nomor 31 Tahun 2009. Jabatan Camat berada dalam eselon III/a.

Kecamatan diberikan anggaran belanja yang cukup sesuai dengan luasnya urusan yang diberikan, yang menurut Wasistiono (2001: 24) bahwa perlunya dipegang dan dijalankan prinsip Money Follow Function artinya fungsi/urusan/ kewenangan yang diserahkan harus pula diikuti dengan penyerahan anggaran belanja yang cukup sesuai kebutuhan (needs).

Fungsi koordinasi dalam pemerintahan termasuk salah satu fungsi eksekutif. Timbulnya fungsi ini sebagai akibat dari pelaksanaan asas organisasi yaitu bagi tugas habis, sehingga masingmasing anggota organisasi hanya mempedulikan pelaksanaan tugasnya masing-masing tanpa memedulikan pelaksanaan tugas dan fungsi pegawai yang lain. Dengan demikian salah satu fungsi fundamental manajemen adalah mengkoordinasikan (coordinating). LAN RI (2003: 154) memberikan makna bahwa "koordinasi adalah salah satu fungsi pokok dari manajemen. Koordinasi selalu diperlukan dalam organisasi yang besar dan kompleks serta dalam kehidupan modern, karena dalam berbagai kegiatan untuk suatu tujuan atau yang berlainan tujuan, selalu ada hal-hal yang saling berkaitan." Tujuan koordinasi adalah untuk memadukan (mengintegrasikan), menyerasikan dan menyelaraskan berbagai kepentingan dan kegiatan yang saling berkaitan beserta segenap gerak, langkah dan waktunya dalam rangka pencapaian tujuan dan sasaran bersama.

Tugas umum pemerintahan kecamatan bidang koordinasi meliputi pemberdayaan masyarakat, ketenteraman dan ketertiban umum, penegakan peraturan perundang-undangan, pemeliharaan prasarana dan fasilitas pelayanan umum. Data pelaksanaan tugas umum pemerintahan dikumpulkan melalui instrumen wawancara, menyangkut fungsi koordinasi, fungsi pembinaan dan fungsi pelayanan masyarakat (public services). Pelaksanaan tugas umum pemerintahan kecamatan Jatinangor menurut Sekretaris kecamatan, adalah,

Pelaksanaan koordinasi Camat sering mengalami kendala terlebih-lebih jika koordinasi tersebut berdampak pada pengeluaran anggaran belanja dan anggaran belanja kecamatan jauh lebih kecil dari unit-unit organisasi di kota kabupaten, sehingga ada kecemburuan sosial dan berdampak kurangnya minat pegawai untuk bekerja di kecamatan" (Bapak Juni, pada 11 November 2011)

Demikian pula rapat pelaksanaan koordinasi setiap bulan antarlembaga termasuk rapat minggon dengan desa-desa di kecamatan belum berjalan secara optimal. Namun dilaksanakan sesuai kebutuhan, serta keterikatan Desa terhadap kecamatan kurang, karena kepala desa cenderung memandang bahwa kepala kecamatan bukan sebagai atasan langsung kepala desa sesuai dengan peraturan perundang-undangan. Berdasarkan informasi Sekretaris Kecamatan Jatinangor tersebut, bahwa pelaksanaan tugas umum pemerintahan kecamatan belum berjalan secara optimal, baik dalam pembinaan karier SDM, koordinasi dengan berbagai lembaga di kecamatan, pembinaan dan pengawasan pemerintahan dan kecukupan anggaran belanja kecamatan.

Pelaksanaan koordinasi diantara Camat dengan Koramil Kecamatan Jatinangor, Kapten Kasno pada tanggal 12 Desember 2011, dikemukakan bahwa "Muspika masih berjalan seperti biasanya, rapat koordinasi dilakukan sesuai kebutuhan, komunikasi dapat dilakukan dengan tatap muka atau dengan handphone."

Informasi wawancara penulis dengan komandan Koramil tersebut dapat dikemukakan bahwa informasi beliau tersebut tentang tugas koordinasi Camat, sinkron dengan informasi yang diberikan oleh perangkat kecamatan yang telah diwancarai oleh penulis sebelumnya. Selanjutnya hubungan kerja dan koordinasi dikemukakan sebagai berikut:

Rapat minggon sekarang tidak harus selalu dengan cara tatap muka, tapi bisa dilaksanakan melalui telepon. Camat berkoordinasi dengan POLSEK dan KORAMIL sesuai kebutuhan. Camat juga dapat melakukan pembinaan dan pengawasan kepada Desa. Kecamatan membuat laporan pelaksanaan tugasnya pada pertengahan bulan yaitu pada tanggal 16 setiap bulan sesuai format yang ditentukan serta diserahkan kepada Bupati melalui Bagian Tata Pemerintahan Sekretariat Daerah Kabupaten Sumedang (Wawancara dengan Bp. Oman. Bagian Tata Pemerintahan, 18 November 2011).

Hasil wawancara tersebut dapat dimaknai bahwa Kecamatan Jatinangor dibina oleh Bagian Tata Pemerintahan Sekretariat Daerah Kabupaten Sumedang. Rapat minggon dan rapat bulanan sudah berjalan sesuai dengan kebutuhan, namun tidak lagi seperti masa lalu di mana rapat wajib dilakukan setiap minggu, komunikasi antarorganisasi tingkat kecamatan Jatinangor dapat dilakukan dengan telepon maupun handphone terlebih-lebih anggaran belanja untuk koordinasi Camat belum memenuhi kebutuhan, sesuai beban tugas dan kewenangan yang diserahkan oleh Bupati.

Pembinaan dapat diartikan sebagai proses kegiatan perubahan sesuatu yang belum baik sebelumnya menjadi lebih baik pada masa depan. Pembinaan menurut Thoha (2008: 207) adalah "suatu tindakan, proses, hasil atau pernyataan menjadi lebih baik." Pembinaan bisa ditujukan kepada orang dan organisasi, agar dapat berfungsi atau memberikan kinerja yang lebih meningkat dari sebelumnya baik dari aspek kualitas maupun 
kuantitas, dalam rangka peningkatan kesejahteraan masyarakat.

Terkait dengan pemerintahan kecamatan maka berdasarkan pasal 15 butir (f) Peraturan Pemerintah No. 19 Tahun 2008, dikemukakan bahwa camat melaksanakan tugas pembinaan penyelenggaraan pemerintahan desa dan/atau kelurahan. Pembinaan penyelenggaraan pemerintahan desa tersebut dilakukan oleh Kecamatan Jatinangor, di antaranya adalah sosialisasi peraturan perundang-undangan, penyuluhan, pendidikan, dan pelatihan, fasilitasi penyusunan RAPBDes, peraturan desa dan sebagainya.

Pembinaan pemerintahan desa berdampak pada pengeluaran anggaran, yang memerlukan perhatian di antara kecamatan dan desa, sebab anggaran untuk pembinaan penyelenggaraan pemerintahan desa terbatas.

Jarak antara ibukota Kecamatan Jatinangor dan kota Sumedang sekitar 20 km, dan jarak ratarata ibu kota kecamatan dan desa-desa di wilayah Kecamatan Jatinangor kurang lebih 2,9 km. Beberapa jenis pelayananan seperti KK, KTP, Perijinan dan sebagainya masih harus diurus ke kota Sumedang, sehingga Kecamatan Jatinangor layak dijadikan sebagai pusat pelayanan masyarakat, karena kecamatan yang terdekat dengan desa-desa dibandingkan dengan kabupaten dengan desa-desa.

Pemerintah Republik Indonesia telah mengeluarkan Peraturan Pemerintah Nomor 79 Tahun 2005, tentang Pedoman Pembinaan dan Pengawasan Penyelenggaraan Pemerintahan Daerah. sebagai pelaksanaan pasal 223 UndangUndang Nomor 32 Tahun 2004, tentang Pemerintahan Daerah, bahwa pembinaan atas penyelenggaraan pemerintahan daerah dilaksanakan oleh Pemerintah yang meliputi koordinasi, pemberian pedoman dan standar, pemberian bimbingan, supervisi dan pendidikan dan pelatihan dan perencanaan, penelitian, pengembangan, pemantauan dan evaluasi pelaksanaan urusan pemerintahan.

Sehubungan dengan hal tersebut tampak bahwa ruang lingkup pembinaan penyelenggaraan pemerintahan itu luas. Pembinaan kepala desa lingkungan Kecamatan Jatinangor menurut Kasi Ketenteraman dan Ketertiban pada tangal 12 Oktober 2011 bahwa "belum jelas pengurusan IMB pada bekas tanah PJKA, kewenangan kecamatan membuat IMB seluas $250 \mathrm{~m} 2$ yang masih harus mendapat rekomendasi dari dinas PU, LH dan Bagian Hukum dan hambatan dalam pembinaan dan pengawasan desa oleh Inspektorat".

Selanjutnya, berkaitan dengan tugas umum kecamatan, Kasi PMD pada tanggal 12 Desember 2011 menjelaskan, "Kepala Desa memandang Camat bukan atasan langsungnya." Hal ini terbukti pada waktu pencairan dana ADD tanpa melalui rekomendasi Camat dan fungsi koordinasi Camat sekarang tidak seperti dulu yaitu adanya rapat minggon, sekarang koordinasi Camat terhadap Desa dan UPTD/UPTB dilakukan sesuai kebutuhan".

Berdasarkan hasil wawancara tersebut dapat dikemukakan bahwa pembinaan dan pengawasan dari kecamatan ke desa belum berjalan secara efektif. Hubungan kerja camat dengan desa kurang intensif. Hubungan kerja desa lebih intensif kepada BPMD daripada ke kecamatan. Sesuai dengan hasil wawancara tersebut di atas tampaknya kepala desa beserta perangkatnya lebih memerhatikan para pegawai dari BPMD. Hal itu menandakan bahwa pelaksanaan tugas umum pemerintahan camat belum berjalan secara efektif.

Kadang-kadang kecamatan dipandang memerlambat suatu urusan, sebagai contoh dalam pencairan ADD (Alokasi Dana Desa), bahwa kepala desa langsung mengurusnya ke BPMD Kabupaten Sumedang tanpa dilengkapi dengan rekomendasi dan/ atau surat pengantar dari Camat, akan tetapi BPMD (Badan Pemberdayaan Masyarakat Desa) memproses usulan desa tersebut. Hal ini menandakan bahwa para Kepala SKPD Kabupaten yang terkait perlu meningkatkan kerjasama antar organisasi dan menghormati tugas pokok dan fungsi masing-masing organisasi. Berdasarkan hasil wawancara diatas dapat dijelaskan bahwa tugas umum pemerintahan kecamatan kompleks, bahkan kecamatan juga melaksanakan tugas-tugas pembantuan baik dari Pusat maupun Daerah.

Pelaksanaan program dan kegiatan kecamatan Jatinangor dilaksanakan berdasarkan DIPA Kecamatan Jatinangor Tahun anggaran 2009 dan 2010. Laporan Akuntabilitas Kinerja Pemerintah (LAKIP) Kecamatan Jatinangor dibuat setiap tahun meliputi: Masukan (Input), Keluaran (Output), Hasil (Outcome), Manfaat (Benefit), dan Dampak (Impact). Menurut catatan Kasubbag Program Setcam Jatinangor bahwa Anggaran belanja masih relatif kecil. Khusus Administrasi umum dan belanja langsung, tanpa belanja Gaji, pada tahun 2009 sebesar Rp. 424.502.348 dan tahun 2010 sebesar Rp. 229.524.475), berarti terdapat penurunan anggaran belanja sebesar sekitar $85 \%$ dari tahun sebelumnya dan besaran anggaran belanja tersebut dinilai terlalu kecil untuk membiayai pelaksanaan tugas umum pemerintahan kecamatan khususnya fungsi pembinaan dan kewenangan yang dilimpahkan oleh Bupati Sumedang kepada camat. Jumlah PNS sebanyak 24 orang yang terdiri dari 1 orang eselon III/a, 1 orang eselon III/b, 5 orang eselon IV/a, 3 orang eselon IV/b dan 15 orang pelaksana serta pemelihara prasarana dan sarana seperti gedung, rumah, kendaraan operasional dan peralatan kantor yang menurut LAKIP Tahun 2010 Kecamatan Jatinangor dinilai masih kurang, baik 
dari aspek kuantitas maupun kualitasnya, sehingga Kecamatan Jatinangor kurang mampu melaksanakan tugas pokok dan fungsi serta kewenangannya secara efektif.

Mustahil kecamatan mampu melaksanakan tugas pokok dan fungsi serta kewenangannya tanpa diikuti dengan penyerahan sumber-sumber daya seperti unsur 3P yang mencukupi kebutuhan. Di sisi lain berdasarkan hasil wawancara dengan para kepala seksi Kecamatan Jatinangor, terdapat kecenderungan bahwa para kepala desa beserta perangkatnya menghindar dari pembinaan camat, kecuali jika kepala desa mengalami hambatan dalam penyelesaian suatu tugas atau urusannya. Hal ini diperkirakan terjadi karena ada pandangan kepala desa bahwa camat bukan sebagai atasan langsungnya.

\section{Pelayanan Masyarakat}

Pembukaan UUD 1945 pada alinea ke empat mengamanatkan bahwa tujuan didirikannya Negara RI di antaranya adalah untuk memajukan kesejahteraan umum dan mencerdaskan kehidupan bangsa. Hal tersebut mengandung makna bahwa negara berkewajiban memenuhi setiap kebutuhan warga negara melalui suatu sistem pemerintahan yang mendukung terciptanya pelayanan publik atau pelayanan masyarakat yang prima dipenuhi kebutuhan dasar dan hak sipil setiap warga negara atas barang publik (public goods), jasa publik dan pelayanan administratif. Hal ini terkait dengan orientasi tata kelola pemerintahan yang baik (GoodGovernance) dewasa ini sebagaimana pendapat Dwiyanto (2008) yang menyatakan, "pelayanan publik menjadi titik strategis bagi pengembangan good governance di Indonesia."

Pelayanan masyarakat atau pelayanan publik menurut Kurniawan dalam Sinambela (2008: 5), adalah pemberian layanan (melayani) keperluan orang atau masyarakat yang mempunyai kepentingan pada organisasi itu, sesuai dengan aturan pokok dan tata cara yang telah ditetapkan. Sedarmayanti (2009: 243) mengatakan bahwa,

\footnotetext{
Pelayanan berarti melayani suatu jasa yang dibutuhkan oleh masyarakat dalam segala bidang kegiatan. Kegiatan pelayanan kepada masyarakat merupakan salah satu tugas dan fungsi administrasi negara. Pelayanan publik berdasarkan UndangUndang Nomor 25 Tahun 2009 adalah kegiatan atau rangkaian kegiatan dalam rangka pemenuhan kebutuhan pelayanan sesuai peraturan perundangundangan bagi setiap warga negara dan penduduk atas barang, jasa dan/atau pelayanan administratif yang disediakan oleh penyelenggara pelayanan publik ". Dengan demikian pelayanan publik yang diselenggarakan oleh penyelenggara pelayanan publik bagi setiap warga negara dan penduduk meliputi barang, jasa dan pelayanan administratif. Pelayanan publik dilaksanakan berdasarkan asasasas pelayanan publik.
}

Jenis-jenis pelayanan masyarakat di Kecamatan Jatinangor sebagai berikut: (1) Pelayanan Kartu Keluarga; (2) Pelayanan KTP; (3) Pelayanan IMB; (4) Ijin Undang-Undang Gangguan (Ho); (5) Ijin Peruntukan Penggunaan Tanah; (6) SK Tinggal Sementara; (7) NIK; (8) SK Pindah antar-Kecamatan; (9) Surat Keterangan Catatan Kepolisian; (10) Pelayanan surat Ahli Waris; (11) Pelayanan Permohonan Kredit Perbankan; (12) Akta Jual Beli; (13) Akta Waris; (14) Akta Hibah dan (15) Dokumen lainnya (Papan Data November 2011).

Berkaitan dengan pelayanan masyarakat, Kasub Bag Program Sekretariat Kecamatan Jatinangor pada tanggal 17 Desember 2011, mengemukakan tugas umum pemerintahan kecamatan bahwa, "pelayanan administrasi kependudukan dipindahkan dari kecamatan ke kota kabupaten Sumedang sehingga biaya pengurusan administasi meningkat dan seharusnya Camat melantik Kepala Desa akan tetapi kenyataannya dilantik oleh Bupati, sehingga mengurangi wibawa Camat."

Berdasarkan hasil wawancara tersebut, dapat dijelaskan bahwa tugas umum pemerintahan kecamatan masih perlu disosialisasikan kepada desa dan perangkat daerah beserta kewenanganya yang ditetapkan dengan Peraturan Bupati Sumedang Nomor 55 tahun 2009. Dengan meningkatnya teknologi informasi, pelayanan masyarakat bisa didekatkan kepada masyarakat di kecamatan bahkan pada saatnya nanti pelayanan masyarakat dapat dipusatkan di desa atau kelurahan. Tenaga-tenaga teknis perangkat daerah yang terkait ditempatkan di kecamatan dibawah koordinasi Camat, hal ini perlu diuji coba. Namun peningkatan pelayanan kepada masyarakat haruslah ditunjang oleh dana yang memadai dan sumber daya manusia (SDM) yang kompeten dan profesional.

Fungsi pelayanan publik tersebut dikelola oleh Seksi Pelayanan Umum Kecamatan Jatinangor. Pelayanan KTP sekarang tidak selesai di Jatinangor, karena kewenangan menerbitkan KTP ada pada Dinas Kependudukan dan Catatan Sipil di Sumedang. Anggota masyarakat yang mengurus KTP ke kota Sumedang terpaksa mengeluarkan biaya tambahan untuk transportasi ke kota Sumedang, lagi pula waktunya pengurusan KTP semakin lama sebagaimana tersebut dalam wawancara penulis diatas. Hal tersebut sesuai dengan pendapat Gasperz (2005) yang menyatakan bahwa birokrasi itu telah kaku dan mati, maka terkait dengan itu pelayanan publik haruslah berfokus kepada masyarakat, karena itu pemerintah harus mampu memandirikan daerah dalam era otonomi daerah sekarang ini termasuk dalam pelayanan E-KTP yang sedang berlangsung dewasa ini. Menurut pengamatan penulis ke 
lapangan bahwa sarana pelayanan di kantor Kecamatan Jatinangor masih kurang, yang masih perlu ditingkatkan.

Faktor kendala atau hambatan lain dalam penyelenggaraan tugas umum pemerintahan Kecamatan Jatinangor berdasarkan LAKIP 2010 dan sumber wawancara dengan Kasubbag Program pada tanggal 17 November 2012, dapat dikemukakan sebagai berikut: jarak kecamatankabupaten: sekitar $20 \mathrm{~km}$, pemindahan pelayanan kependudukan ke kabupaten, pendidikan PNS (24) umumnya sosial, belum jelas juklak dan juknis tentang kewenangan yang dilimpahkan oleh Bupati, belum jelas hubungan kecamatan dengan UPTD/ UPTB, rendahnya tingkat koordinasi dan pengendalian (Desa; UPTD/UPTB), rendahnya anggaran belanja kecamatan, kurangnya prasana dan sarana kedinasan, dan tumpang tindihnya tugas umum pemerintahan kecamatan dengan beberapa perangkat daerah.

\section{Pemberdayaan Pemerintah Kecamatan}

Untuk mewujudkan Pemerintah Kecamatan Jatinangor sebagai pusat pelayanan masyarakat, maka pemerintah Kecamatan Jatinangor harus diberdayakan, dalam arti ia lebih diberi kekuasaan dan sumber-sumber daya (orang, uang dan sarana prasarana) sehingga Pemerintah Kecamatan Jatinangor menjadi lebih mandiri. Pemberdayaan (empowerment) adalah proses membuat orang atau organisasi menjadi lebih mampu dan mandiri. Hal ini sesuai dengan pernyataan Shalimow (2009) bahwa konsep pemberdayaan adalah membantu masyarakat agar bisa menolong diri sendiri. Dia mengutip pendapat Freire dalam Sutrisno (1999) yang menyatakan bahwa empowerment bukan sekedar memberikan kesempatan menggunakan sumber-sumber daya dan biaya pembangunan saja, tetapi upaya untuk mendorong mencari cara menciptakan kebebasan dari struktur yang opresif. Pranarka dalam Justina (2008) mengemukakan tentang hakekat pemberdayaan masyarakat bahwa, ada tiga aspek pemberdayaan yaitu power to nobody (penghapusan kekuasaan), power to every body (pembagian kekuasaan kepada setiap orang) dan penguatan kepada yang lemah tanpa menghancurkan yang kuat.

Salah satu aspek pemberdayaan pemerintah kecamatan adalah reformasi administrasi atau reformasi birokrasi dengan tujuan untuk meningkatkan efektivitas organisasi dan mengobati penyakit administrasi (Zauhar, 1996). Untuk mewujudkan reformasi administrasi diperlukan kepemimpinan yang transformasional yang berorientasi pada perubahan positif pada pengikutnya (Yukel, Gary, 2009).

Organisasi kecamatan yang dibentuk selama ini cenderung seragam di seluruh wilayah pemerintahan daerah di Indonesia. Wasistiono (2002) menghendaki agar "organisasi kecamatan sebagai organisasi pemberi pelayanan (service organization) bukan lagi sebagai organisasi penekan (pressure organization). Oleh karena itu, unsur lini berupa seksi-seksi memegang peranan penting, karena unit ini memberikan pelayanan langsung kepada masyarakat dan perlu peningkatan kualitas SDM aparatur kecamatan harus dimulai dari unsur lini (seksi-seksi)". Sehubungan dengan itulah maka Wasistiono (2002), mengemukakan bahwa:

Ada dua pola organisasi kecamatan yaitu pola seragam dan pola beraneka ragam sesuai dengan besar dan luasnya kewenangan yang didelegasikan yang memiliki kelebihan dan kekurangannya masing-masing.

Pola beranekaragam memiliki dua varian yaitu tanpa cabang dinas dan dengan cabang dinas. Organisasi kecamatan dengan cabang dinas apabila cabang dinas itu meliputi beberapa kecamatan dan dengan tanpa cabang dinas jika wilayah kerjanya hanya satu kecamatan, cukup dimasukkan menjadi salah satu seksi di dalam organisasi kecamatan.

Berdasarkan uraian tersebut dapat dikemukakan tiga alternatif pemberdayaan organisasi Kecamatan Jatinangor, yaitu:

\section{Aspek Organisasi}

Jika ditempuh dengan cara cabang Dinas atau LTD yang meliputi beberapa kecamatan. hubungan cabang Dinas atau LTD di wilayah kecamatan bersifat koordinatif, jika ditempuh dengan cara Cabang Dinas atau LTD yang meliputi satu kecamatan, maka pegawai Dinas atau LTD tersebut, dimasukkan dalam salah satu unit/seksi di dalam organisasi kecamatan. Secara teknis ia mendapat pembinaan teknis fungsional dari Dinas atau LTD-nya, namun secara teknis operasional sehari-hari ia berada di bawah dan bertanggungjawab kepada Camat dan cara yang ketiga yaitu dengan mereformasi organisasi kecamatan yang baru, yang diisi dengan jabatanjabatan yang sesuai dengan kebutuhan dan kewenangan yang dilimpahkan dalam rangka kecamatan sebagai pusat pelayanan masyarakat. Sehubungan dengan uraian tersebut diatas maka bagan organisasi Kecamatan Jatinangor yang diusulkan adalah sebagaimana pada gambar 1 .

Pelayanan harus didekatkan kepada masyarakat, hal itu berarti bahwa Pemerintah Kecamatan Jatinangor dijadikan sebagai pusat pelayanan masyarakat, karena Kecamatan Jatinangor sebagai ujung tombak yang terdekat dengan masyarakat desa. Bagan organisasi kecamatan sebaiknya tidak didesain secara seragam seperti selama ini, akan tetapi disesuaikan dengan potensinya. Camat berada dibawah dan bertanggung jawab kepada Bupati melalui 


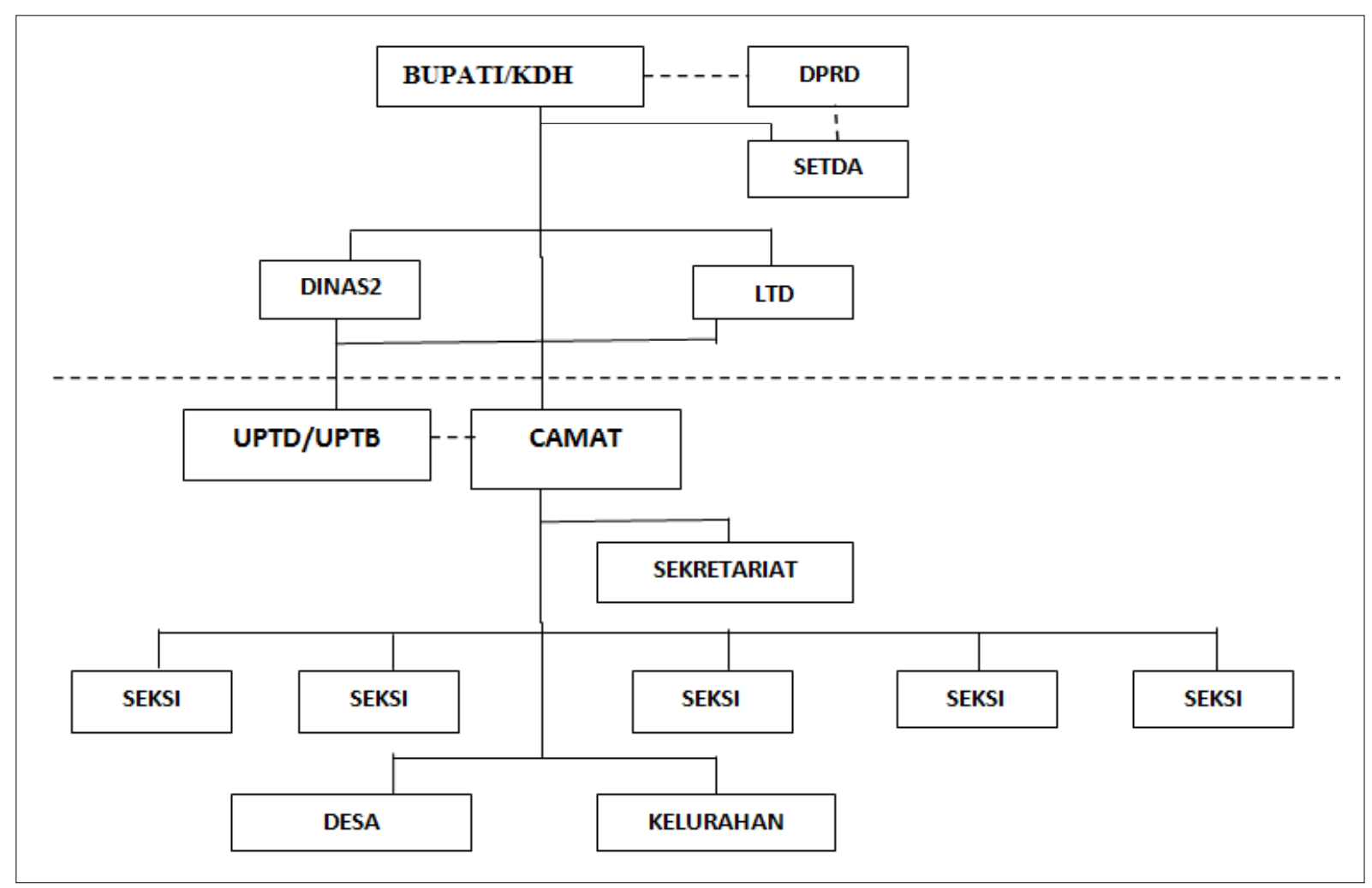

\section{Gambar 1 \\ Alternatif Bagan SOTK Kecamatan Jatinangor}

Sumber: Wasistiono (2002) dan Data Potensi Kec. Jatinangor, Modifikasi Penulis, 2011.

Sekretaris Daerah. Untuk kesatuan komando maka Kepala Desa dan Kepala Kelurahan berada dibawah dan bertanggungjawab kepada Camat.

\section{Aspek Kewenangan}

Bupati Sumedang membuat kebijakan dalam pemberdayaan Kecamatan Jatinangor sebagai pusat pelayanan masyarakat memberikan kewenangan yang cukup dan jelas dalam ruang lingkupnya dan dilengkapi dengan petunjuk pelaksanaan dan petunjuk teknis.

\section{Aspek Pelayanan}

Menurut penulis bahwa semua jenis pelayanan masyarakat harus dapat diselesaikan di Kantor Pemerintah Kecamatan Jatinangor, untuk itu unsur 3P (Personalia, Pembiayaan dan Prasarana dan Sarana) diberikan oleh Bupati Sumedang dengan kemauan, keberanian, komitmen dan konsistensi dalam membuat dan melaksanakan kebijakan, sesuai dengan besar dan luasnya tugas dan kewenangan yang dilimpahkan kepada Camat sebagaimana yang berlaku pada perangkat daerah lainnya di kota Kabupaten Sumedang, dengan menggunakan teknologi IT.

Menurut kajian administrasi pemerintahan, kehadiran organisasi kecamatan masih sangat diperlukan, karena mustahil Bupati membina secara langsung pemerintahan desa yang jumlahnya sebanyak 279 desa di Kabupaten Sumedang berdasarkan data tahun 2009, karena itu Bupati seharusnya tidak ragu-ragu untuk memberdayakan pemerintah Kecamatan Jatinangor sebagai ujung tombak, untuk mewujudkan pelayanan prima kepada masyarakat. Ada dua belas desa di bawah pembinaan Camat Jatinangor, yaitu: Desa Cikeruh (CKR); Desa Hegarmanah(HM); Desa Cibeusi (CBS); Desa Cipacing (CIP); Desa Sayang (SAY); Desa Mekargalih (MGL); Desa Cintamulya (CIMUL); Desa Jatimukti (JAMUK); Desa Cisempur (CPUR); Desa Jatiroke(JTR); Desa Cileles (CILES); Dan Desa Cilayung (CLYUG).

Berdasarkan data orbitasi Desa ke Ibukota kecamatan, maka rata-rata jarak desa ke Ibukota Kecamatan Jatinangor adalah sekitar 2,9 km dan Jarak Ibukota Kecamatan Jatinangor ke Ibukota Kabupaten Sumedang adalah sekitar $20 \mathrm{~km}$. Ada beberapa jenis pelayanan seperti kependudukan, ijin-ijin dan lainnya yang memerlukan waktu, tenaga dan biaya pengurusan yang tidak sedikit selama ini, maka untuk mendekatkan pelayanan kepada masyarakat, Pemerintah Kecamatan Jatinangor sebaiknya diberdayakan sebagai pusat pelayanan kepada masyarakat dengan memenfaatkan teknologi komunikasi dan informasi diantara para stakeholders yang terkait. 


\section{Simpulan dan Saran}

Pelaksanaan tugas umum pemerintahan Kecamatan Jatinangor bidang koordinasi, pembinaan dan pelayanan masyarakat belum berjalan secara optimal. Belum terwujud keseimbangan antara hak dan kewajiban kecamatan. Kendala yang dihadapi kecamatan yaitu kekurangan unsur 3P (Personalia, Pembiayaan dan Prasarana dan Sarana) dalam merealisikan tugastugas yang bersifat atributif dan tugas-tugas yang bersifat delegatif yang luas dan kompleks, kekurang jelasan kewenangan yang dilimpahkan oleh Bupati kepada camat dan kurangnya upaya pemberdayaan pemerintah kecamatan sebagai pusat pelayanan masyarakat.

Bupati Sumedang agar supaya dalam melaksanakan tugas pokok dan fungsi serta pelimpahan sebagian kewenangan kepada Kecamatan Jatinangor diikuti dengan pemberian unsur 3P (Personalia, Pembiayaan, dan Prasarana dan Sarana) yang mencukupi kebutuhan dan untuk mewujudkan Pemerintah Kecamatan Jatinangor sebagai pusat pelayanan masyarakat perlu menata ulang Organisasi Kecamatan Jatinangor sebagai percontohan, melalui perubahan struktur, kewenangan yang jelas dan penyediaan sumbersumber daya yang dibutuhkan serta disisi lain Pemerintah Kecamatan Jatinangor perlu membuat Daftar Inventarisasi Masalah (DIM) sebagai bahan masukan bagi Bupati Sumedang dalam mengambil keputusan untuk pemecahan masalah yang dihadapi.

\section{Daftar Pustaka}

Alie, F. (2004). Filsafat Administrasi, Jakarta, PT. Raja Grafindo Persada.

Arikunto, S. (2002). Prosedur Penelitian (suatu pendekatan praktek), Jakarta, Rineka Cipta.

Dwiyanto, A. (2008), Mewujudkan Good Governance Melalui Pelayanan Publik, Yogyakarta, Gama University Press.

Gasperz, V. (2005), Sistem Manajemen Kinerja Tertintegras Balanced Scorecard Dengan Six Sigma Untuk Organisasi Bisnis dan Pemerintah, Jakarta, PT. Gramedia Pustaka Utama.

LAN RI. (2003) Sistem Administrasi Negara Kesatuan Republik Indonesia, Jakarta, Perum Percetakan Negara RI.

(2004) "Sistem Administrasi Negara Kesatuan Republik Indonesia", Jakarta, CV Raga Meulaba.

Nazir, Moh. (2005). Metode Penelitian, Ghalia Indonesia, Jakarta, Gunung Agung.

Nugroho, D, Riant.(2003). Kebijakan Publik, Formulasi, Implementasi dan Evaluasi, Jakarta, PT. Elex Media Komputindo.

Sedarmayanti, (2009). Reformasi Administrasi Publik, Reformasi Birokrasi Dan Kepemimpinan
Masa Depan, Bandung, Aditama.

Shafritz, at.al. (2011), Introducing Public Administration, USA, Pearson Education, Inc.

Siagian, S. P. (2008). "Filsafat Administrasi", Jakiarta, Bumi Aksara.

Sinambela, (2008), Reformasi Pelayanan Publik, Jakarta, Bumi Aksara;

Thoha, M. (2008). Ilmu Administrasi Publik Kontemporer, Jakarta, Kencana.

Smith, B.C., (2007), Good Governance and Development, New Work, Palgrave Macmilan.

Wasistiono, S. (2001). Esensi Undang-Undang Nomor 22 Tahun 1999 Tentang Pemerintahan Daerah, Bandung, Alqa Print.

(2002). Kapita Selekta Penyelenggaraan Pemerintahan Daerah, Bandung, Alqa Print.

Yukl, G , (2009). Kepemimpinan Dalam Organisasi, Jakarta, PT Indeks.

Zauhar, Soesilo,(1996), Reformasi Administrasi, Jakarta, Bumi Aksara.

Dokumen:

Undang - Undang Dasar 1945.

Undang - Undang Nomor 32 Tahun 2004 Tentang Pemerintahan Daerah.

Undang-Undang Nomor 25 Tahun 2009, Tentang Pelayanan Publik.

Peraturan Pemerintah Nomor 79 Tahun 2005, Tentang Pedoman Pembinaan dan Pengawasan Penyelenggaraan Pemerintahan /Daerah.

Peraturan Pemerintah Nomo 19 Tahun 2008 Tentang Kecamatan.

Peraturan Pemerintah No. 41 Tahun 2007 Tentang Oganisasi Perangkat Daerah.

Peraturan Daerah Kabupaten Sumedang Nomor 8 Tahun 2008 Tentang Pembentukan Kecamatan.

Peraturan Bupati Sumedang Nomor 55 Tahun 2009, Tentang Pelimpahan Kewenangan Kepada Camat Dilingkungan Pemerintahan Kabupaten Sumedang.

Peraturan Bupati Sumedang Nomor 31 Tahun 2009, Tentang UraianTugas Jabatan Struktural Pada Kabupaten Sumedang.

Shalimow, Yunan, 2009, Konsep Pemberdayaan, (http://www.pemberdayaan.com/) diundah tanggal 2 September 2011.

Justina, 2008, Pemberdayaan Masyarakat Desa Di Kecamatan Panobeian Panei Kabupaten Simalungun, Medan, USU.

LAKIP Kecamatan Jatinangor Tahun 2009 dan Tahun 2010.

Zamzami, Lucky, 2011, Pemberdayaan Ekonomi Masyarakat Pesisir di Nagari Ampiang Perak, Sumtera Barat, Jurnal Sosial dan Pembangunan "Mimbar"Volume XXVII, No.1 (Juni 2011) 1-124.

LAN dan BPKP, (2000). Akuntabilitas dan Good Governance, Jakarta, Modul AKIP. 